\title{
Enhanced Biological Control of Phytophthora Blight of Pepper by Biosurfactant-Producing Pseudomonas
}

\author{
Ümit Özyilmaz and Kemal Benlioglu* \\ Adnan Menderes University, Faculty of Agriculture, Plant Protection Dept. 09100/Aydin, Turkey \\ (Received on February 20, 2013; Revised on May 3, 2013; Accepted on May 20, 2013)
}

\begin{abstract}
Pseudomonas isolates from different crop plants were screened for in vitro growth inhibition of Phytophthora capsici and production of biosurfactant. Two in vivo experiments were performed to determine the efficacy of selected Pseudomonas strains against Phytophthora blight of pepper by comparing two fungicide treatments [acibenzolar-S-methyl (ASM) and ASM + mefenoxam]. Bacterial isolates were applied by soil drenching $\left(1 \times 10^{9}\right.$ cells $/ \mathrm{ml}), \operatorname{ASM}(0.1 \mu \mathrm{g}$ a.i. $/ \mathrm{ml})$ and ASM + mefenoxam $(0.2 \mathrm{mg}$ product $/ \mathrm{ml})$ were applied by foliar spraying, and $P$. capsici inoculum was incorporated into the pot soil three days after treatments. In the first experiment, four Pseudomonas strains resulted in significant reduction from 48.4 to $61.3 \%$ in Phytophthora blight severity. In the second experiment, bacterial treatments combining with olive oil ( $5 \mathrm{~mL}$ per plant) significantly enhanced biological control activity, resulting in a reduction of disease level ranging from 56.8 to $81.1 \%$. ASM + mefenoxam was the most effective treatment while ASM alone was less effective in both bioassays. These results indicate that our Pseudomonas fluorescens strains (6L10, 6ba6 and 3ss9) that have biosurfactant-producing abilities are effective against $P$. capsici on pepper, and enhanced disease suppression could be achieved when they were used in combination with olive oil.
\end{abstract}

Keywords : biocontrol, biosurfactant, olive oil, Phytophthora capsici, Pseudomonas

Turkey is the third-largest pepper producer in the world and produces approximately 1.98 million metric tons of chilies and peppers in an area of 99,000 hectares (FAO, 2010). Phytophthora blight of pepper, caused by Phytophthora capsici (Leonian), is one of the most economically destructive soil-borne diseases of pepper (Capsicum annuиm L.) in nearly all of the world's major pepper-growing countries, including China (Ma et al., 2008), Mexico (Robles-Yerena et al., 2010), Turkey (Akgül and Mirik,

\footnotetext{
*Corresponding author.

Phone) +90-256-7727023, FAX) +90 256-7727233

E-mail)kbenlioglu@adu.edu.tr
}

2008), Spain (Silvar et al., 2006), the United States of America (Hausbeck and Lamour, 2004) and Nigeria (Alegbejo et al., 2006). Since it was first described in 1974 (Baris et al., 1986), P. capsici has been a major disease limiting pepper fruit production in Turkey (Ölmez, 2006).

There are numerous reports related to the suppression of P. capsici on pepper plants using chemical (Hausbeck and Lamour, 2004) and microbial (Kim et al., 2010) fungicides. Biological control is a promising and sustainable approach for the effective management of $P$. capsici due to problems such as environmental or human health hazards (Hausbeck and Lamour, 2004), phytotoxicity (Foster and Hausbeck, 2010) and fungicide resistance (Lamour and Hausbeck, 2001). Bacteria that have been used for this purpose include Actinomyces spp. (Ezziyyani et al., 2007; Hee et al., 2006; Lee and Hwang, 2002), Burkholderia cepacia (Ezziyyani et al., 2004; Lee et al., 1999), Pseudomonas spp. (Jung and Kim, 2004; Lee et al., 1999; Lee et al., 2003a, b, c), Serratia marcescence (Okomoto et al., 1998), Serratia plymuthica (Shen et al., 2005), rhizobacteria (Sang et al., 2008), Bacillus spp. (Akgül and Mirik, 2008; Aravind et al., 2009; Chung et al., 2008; Dai and Guan, 1999; Guillén-Cruz et al., 2006; Jiang et al., 2006; Jung and Kim, 2003; Jung and Kim, 2005; Lee and Hwang, 2002; Qiu et al., 2004; Sid et al., 2003; Zhang et al., 2010).

One relevant innovation in this area was the potential of biosurfactants for biological control of zoospore-producing plant pathogens (Stanghellini and Miller, 1997). Since this work, additional reports have appeared demonstrating the possible use of biosurfactant-producing bacteria for the control of P. capsici (Kim et al., 2000; Nielsen et al., 2006). The genus Pseudomonas comprises important biocontrol agents that are capable of using different substrates such as glycerol, mannitol, fructose, glucose, $n$-paraffins, and vegetable oils, to produce biosurfactants (Abouseoud et al., 2008). Olive oil has been identified as a probable substrate that would support selective growth of rhamnolipidproducuing bacteria as well as enhance rhamnolipid synthesis (Abouseoud et al., 2008; Stanghellini and Miller, 1997).

The objective of this study was to evaluate the effects of 
biosurfactant-producing Pseudomonas alone or in combination with olive oil on controlling Phytophthora blight of pepper caused by $P$. capsici.

\section{Material and Methods}

Bacterial isolates and preliminary screen. Pseudomonas strains were isolated from roots of pepper, strawberry, cabbage, cauliflower, broccoli, broad bean and radish fields in the main cultivation areas of Aydin province of Turkey. For bacterial isolations, plant roots were washed under running tap water, and $3 \mathrm{~g}$ of roots from each plant were blended in a stomacher (BagMixer ${ }^{\circledR}$, Interscience) in $27 \mathrm{~mL}$ of physiological saline $(0.9 \% \mathrm{NaCl}, \mathrm{pH} 7.0)$ for $1 \mathrm{~min}$. Aliquots of suspensions were plated on King's B medium (King et al., 1954) and incubated at $25^{\circ} \mathrm{C}$ for $48 \mathrm{~h}$. Single bacterial colonies were transferred to King's B medium for purity, and cultures were cryopreserved with $15 \%$ glycerol at $-80{ }^{\circ} \mathrm{C}$.

Pseudomonads isolates were tested for their ability to produce antifungal substances against $P$. capsici using a dual-culture in vitro assay on potato dextrose agar (PDA) plates. Standardized bacterial suspensions $\left(3 \times 10^{8}\right.$ cells $\left./ \mathrm{mL}\right)$ were prepared from overnight cultures of Pseudomonas isolates on King's B medium. One $10 \mu \mathrm{L}$ droplet of bacterial suspension was applied to each of four points symmetrically placed on sites at equal distances $(2.5 \mathrm{~cm})$ from the center of each PDA plate. After $24 \mathrm{~h}$ of incubation at $24{ }^{\circ} \mathrm{C}$, a single $10 \mathrm{~mm}$ diameter mycelial disc was placed in the center of the plate. As a control, a disc of $P$. capsici was grown on a PDA plate. The diameter of each fungal colony was measured along two perpendicular axes after a 10 day incubation at $24{ }^{\circ} \mathrm{C}$ in darkness, and the percentage inhibition of mycelial growth was calculated.

Antagonistic Pseudomonads were later assayed for biosurfactant production with the mineral salt-CTAB-methylene blue agar plate method originally described by Siegmund and Wagner (1991). Ten microliters of bacterial suspension $\left(10^{8}\right.$ cells $\left./ \mathrm{mL}\right)$ was pipetted onto the center of one square $(1.5 \times 1.5 \mathrm{~cm})$ of the $4 \times 4$ grid drawn on the bottom of the plate containing mineral salt-CTAB-methylene blue agar. The plates were then incubated at $30^{\circ} \mathrm{C}$ for $48 \mathrm{~h}$. Biosurfactant activity was evaluated by measuring the diameters of the blue halos around the colonies after incubating the plates at $4{ }^{\circ} \mathrm{C}$ for $24 \mathrm{~h}$. The Pseudomonas strains selected in this work and relevant information on their identities, based on fatty acid analysis (FAME) are listed in Table 1.

Table 1. In vitro antagonism against Phytophthora capsici and production of antifungal metabolites by Pseudomonas isolates from the rhizospheres of different plants

\begin{tabular}{|c|c|c|c|c|c|c|c|c|c|c|c|}
\hline Isolates & Species & Origin & $\begin{array}{l}\text { In vit } \\
\text { inhibiti }\end{array}$ & & $\begin{array}{c}\text { Bio- } \\
\text { surfactant }^{\mathrm{b}}\end{array}$ & $\begin{array}{c}\mathrm{P} \\
\text { solubilization }^{\mathrm{c}}\end{array}$ & $\mathrm{IC}^{\mathrm{d}}$ & $\mathrm{HCN}^{\mathrm{e}}$ & $\begin{array}{l}\text { Sidero- } \\
\text { phore }^{\text {f }}\end{array}$ & $\operatorname{phlD^{\mathrm {g}}}$ & Protease $^{\mathrm{h}}$ \\
\hline $6 \mathrm{ba} 6$ & P.fluorescens & Broad bean & 100.0 & $\mathrm{a}$ & +++ & + & + & ++ & +++ & + & ++ \\
\hline $6 \mathrm{ba} 2$ & Pseudomonas sp. & Broad bean & 100.0 & $\mathrm{a}$ & +++ & - & + & +++ & +++ & + & ++ \\
\hline $6 \mathrm{ba3}$ & Pseudomonas sp. & Broad bean & 90.4 & $\mathrm{~b}$ & ++ & ++ & + & ++ & +++ & + & + \\
\hline $6 \mathrm{t} 14$ & Pseudomonas sp. & Radish & 86.7 & $\mathrm{~b}$ & ++ & + & +++ & + & +++ & + & - \\
\hline $3 \mathrm{ss} 9$ & P.fluorescens & Strawberry & 71.1 & $\mathrm{c}$ & +++ & + & + & +++ & ++ & + & + \\
\hline $6 \mathrm{~L} 10$ & P. fluorescens & Cabbage & 57.8 & $\mathrm{~d}$ & +++ & ++ & ++ & +++ & ++ & + & ++ \\
\hline ke & P. fluorescens & Strawberry & 56.7 & $\mathrm{~d}$ & ++ & ++ & + & +++ & ++ & + & + \\
\hline $3 \mathrm{k} 9$ & P.fluorescens & Strawberry & 51.8 & e & +++ & + & + & +++ & ++ & + & + \\
\hline $6 \mathrm{~L} 14$ & P.fluorescens & Cabbage & 50.6 & e & ++ & + & + & +++ & ++ & + & ++ \\
\hline $\mathrm{mbj}$ & P.fluorescens & Strawberry & 49.3 & $\mathrm{e}$ & ++ & ++ & + & +++ & ++ & + & + \\
\hline $3 \operatorname{tg} 8$ & Pseudomonas sp. & Strawberry & 38.6 & $\mathrm{f}$ & ++ & ++ & ++ & + & ++ & + & - \\
\hline
\end{tabular}

${ }^{a}$ Mean percent inhibition (relative to the radius of hyphal growth of $P$. capsici in control) in dual culture assay; values followed by the same letter are not significantly different, according to Tukey's HSD test at $P=0.05$

${ }^{\mathrm{b}}$ Biosurfactant production, according to Siegmund and Wagner (1991): (+++>20 mm-wide blue zone; ++ 10-20 mm-wide blue zone; - absent) ${ }^{\mathrm{c}}$ Inorganic phosphate solubilization, based on plate assay on TCP medium (De Freitas et al., 1997): (++ 10-20 mm-wide clear zone; $+5-10$ mmwide clear zone; - absent)

${ }^{\mathrm{d}}$ Indolic compounds (IC) production, assayed by the colorimetric method of Patten and Glick $(2002):(+++>1 \mu \mathrm{g} / \mathrm{mL} ;++0.5-1 \mu \mathrm{g} / \mathrm{mL},+0.1-$ $0.5 \mu \mathrm{g} / \mathrm{mL} ;$ - absent)

${ }^{\mathrm{e}}$ Hydrogen cyanide activity, based on color change of filter paper , according to Bakker and Schippers $(1987):(+++$ strong; ++ moderate; + weak; - absent)

${ }^{\mathrm{f}}$ Siderophores, according to Schwyn and Neilands (1987): (+++>20 mm-wide orange zone; ++ 10-20 mm-wide orange zone; + 5-10 mm-wide orange zone; - absent)

${ }^{\mathrm{g}}$ Detection of the phlD gene (629-bp product) by PCR (McSpadden Gardener, 2001)

${ }^{\mathrm{h}}$ Protease activity, determined by plate assay of Krachel et al. (2002): $(+++>10$ mm-wide clear zone; $++5-10$ mm-wide clear zone; $+<5$ mmwide clear zone, - absent) 
Mechanism of action of selected Pseudomonas strains. Solubilization of inorganic phosphate. The ability of selected Pseudomonas strains to solubilize tricalcium orthophosphate (TCP) was tested on TCP medium (De Freitas et al., 1997). Ten $\mu \mathrm{L}$ of bacterial suspension $\left(10^{8}\right.$ cells $\left./ \mathrm{mL}\right)$ from each of 11 Pseudomonas isolates was dropped onto the center of one square $(1.5 \times 1.5 \mathrm{~cm})$ of the $4 \times 4$ grids drawn on the bottoms of the plates containing TCP. After incubation at $25^{\circ} \mathrm{C}$ for 7 days, the presence of a clear zone around the colony indicated phosphate-solubilizing activity of the bacterial isolates, and the diameters of the clear halos were measured in millimeters.

Production of indolic compounds. Production of indolic compounds by bacteria was examined using a colorimetric method described by Patten and Glick (2002). Pseudomonas isolates was first cultured in $5 \mathrm{~mL}$ tryptic soy broth at $25^{\circ} \mathrm{C}$ overnight. To synchronize the cells of each isolate, two consecutive $24 \mathrm{~h}$ transfers were made with $20 \mu \mathrm{L}$ of inoculum, and then $20 \mu \mathrm{L}$ aliquots were transferred into 5 $\mathrm{mL}$ of DF salts minimal media (Dworkin and Foster, 1958), supplemented with the following concentrations of Ltryptophan $0,0.1,0.5,1,5,10,50$ and $100 \mu \mathrm{g} / \mathrm{mL}$. After incubation for $42 \mathrm{~h}$, the bacterial cells were then removed from the culture medium by centrifugation at 5,500 $\mathrm{g}$ for 10 min. A $1 \mathrm{~mL}$ aliquot of each supernatant was mixed vigorously with $4 \mathrm{~mL}$ of Salkowski's reagent (Gordon and Weber, 1951) and allowed to stand at room temperature for $20 \mathrm{~min}$ before the absorbance at $535 \mathrm{~nm}$ was measured. The concentration of indolic compounds in each culture medium was determined by comparison with a standard curve.

Production of cyanide. Production of hydrogen cyanide (HCN) was determined using a modification of the procedure of Bakker and Schippers (1987). The Pseudomonas isolates were grown in screw-cap test tubes containing 5 $\mathrm{mL}$ of King's B broth supplemented with $4.4 \mathrm{~g} / \mathrm{L}$ of glycine, with filter paper strips soaked in picric acid solution $(0.5 \%$ picric acid and 2.0\% $\mathrm{Na}_{2} \mathrm{CO}_{3}$ ) placed in the cap of each tube. The cap of the tubes were sealed with Parafilm ${ }^{\circledR}$ and incubated in an orbital shaker at $20^{\circ} \mathrm{C}$ for $96 \mathrm{~h}$. Microbial production of cyanide was determined by a color shift from yellow to brown in the filter paper (Castric, 1975). Reactions were scored as weak (yellow to light brown), moderate (brown), or strong (reddish brown) for each of the Pseudomonas strains.

Production of siderophores. Pseudomonas strains were grown on universal siderophore detection medium CAS agar plates (Schwyn and Neilands, 1987). Droplets of 10 $\mu \mathrm{L}$ of bacterial suspensions $\left(10^{8}\right.$ cells $\left./ \mathrm{mL}\right)$ were spotted onto CAS agar plates with $4 \times 4$ grid patterns. Siderophore production was calculated as the diameter of the orange halo around the colonies as measured after $72 \mathrm{~h}$ of incubation at $25^{\circ} \mathrm{C}$.

Presence of phlD gene. The ability of the Pseudomonas strains to produce antibiotics was analyzed by PCR amplification of a phlD-related gene using the primer pair B2BF and BPR4 (McSpadden Gardener et al., 2001). Template DNA was prepared by boiling $200 \mu \mathrm{L}$ of bacterial suspension in MilliQ water for $13 \mathrm{~min}$ followed by immediate chilling on ice, and then centrifugation at 13,000 $\mathrm{g}$ for $3 \mathrm{~min}$ at $4{ }^{\circ} \mathrm{C}$. Two microliters of the supernatants was used directly in $20 \mu \mathrm{L}$ PCR mix. The generation of a $629 \mathrm{bp}$ product indicated the presence of the phlD gene.

Extracellular enzyme activities. The abilities of individual Pseudomonas strains to produce extracellular lytic enzymes, such as chitinase, protease and cellulase, were determined by spot inoculation of $10 \mu \mathrm{L}$ of bacterial suspension prepared from $24 \mathrm{~h}$ old nutrient agar cultures on substrates containing appropriate media (Berg et al., 2000). Chitinase activity was assayed by inoculating chitin-agar plates. The clear halos, indicating enzymatic degradation of chitin, were measured after five days of incubation at $30{ }^{\circ} \mathrm{C}$. Screening for cellulase producers was done on carboxymethylcellulose agar (Kasana et al., 2008). After incubation at $28^{\circ} \mathrm{C}$ for $48 \mathrm{~h}$, the plates were flooded with Gram's iodine for 3 to $5 \mathrm{~min}$, and they were observed for zones of clearance around the colonies. Protease activity, indicated by casein degradation, was determined from clearing zones in skim milk agar after 5 days of incubation at $20{ }^{\circ} \mathrm{C}$ (Krechel et al., 2002).

Greenhouse experiment. For greenhouse assays, Pseudomonas strains were applied as a soil drench. Bacterial suspensions from $24 \mathrm{~h}$ old bacterial streak cultures adjusted to $1 \times 10^{9} \mathrm{cfu} / \mathrm{mL}$ with sterilized distilled water were used for inoculation. One highly virulent single-spore culture of P. capsici strain Pc-101 isolated from pepper plants in Aydin province was used in all experiments. The fungus was routinely stored as agar plugs in sterile distilled water at room temperature and inoculum was prepared using a method of Kurze et al. (2001). Eight, $6 \mathrm{~mm}$-diameter mycelial plugs from one-week-old cultures of $P$. capsici were used to inoculate a $250 \mathrm{~mL}$ mixture of wheat bran: vermiculite (1:1) containing $30 \mathrm{~g}$ of soybean flour and 84 $\mathrm{mL}$ of distilled water. This mixture was incubated at $22^{\circ} \mathrm{C}$ for 28 days and incorporated into an autoclaved soil:sand: peat $(1: 1: 1)$ mixture at a final concentration of $1 / 100(\mathrm{v} / \mathrm{v})$.

Two experiments were performed to determine the effectiveness of the selected Pseudomonas strains for sup- 
pression of Phytophthora blight of pepper with artificial inoculation under controlled greenhouse conditions by comparing the efficiency of acibenzolar-S-methyl (ASM) (Bion $^{\circledR} 50$ WG, Syngenta Crop Protection Inc.) and acibenzolar-S-methyl (4\%) + mefenoxam (40\%) (Bion MX $\mathrm{MX}^{\circledR} 44$ WG, Syngenta Crop Protection Inc.). Two-week-old pepper (cv. California Wonder) seedlings were transplanted into 10 cm-diameter $(500 \mathrm{ml})$ plastic pots containing $380 \mathrm{ml}$ of autoclaved soil:sand:peat (1:1:1) mixture. Plants were incubated at $25 \pm 2{ }^{\circ} \mathrm{C}$ with a 14-h photoperiod and fertilized once a week with liquid fertilizer (Sheffer 16-8-24 N-P-K plus micronutrients).

In the first experiment, the six Pseudomonas strains (6L10, 6ba6, 3ss9, mbj, 6ba2 and 3k9) were selected from 11 biosurfactant-producing Pseudomonas isolates by comparing their biocontrol activities. Twenty-five milliliters of bacterial suspension, prepared as described above, was applied by soil drench at the base of the stem of each pepper plant immediately after transplanting. Chemicals were applied three weeks after transplanting by thoroughly spraying pepper plants with $25 \mathrm{~mL}$ of a solution of acibenzolar$S$-methyl $(0.1 \mu \mathrm{g}$ a.i. $/ \mathrm{mL})$ and acibenzolar-S-methyl + mefenoxam $(0.2 \mathrm{mg}$ product $/ \mathrm{mL})$ with the excess fungicide running into the potting mix. Plants were also treated with 25 $\mathrm{mL}$ of sterile distilled water by soil drench for the untreated control. After 3 days of chemical treatments, when the plants were about 5-week-old, $4 \mathrm{~mL}$ of Phytophthora inoculum, prepared as described above, was mixed homogeneously with $20 \mathrm{~mL}$ of autoclaved soil:sand:peat (1:1:1) mixture, and the resulting inoculum was mixed thoroughly and carefully with the upper $1-2 \mathrm{~cm}$ of soil in each pot of all treatment plots, avoiding injury to lateral roots of the plants. The pots were watered immediately after oomycete inoculation. Three weeks after pathogen inoculation, the severity of symptoms was assessed in terms of the mean disease severity index (DSI) of plants with a scale where $0=$ healthy plant; 1 $=$ older leaves wilted, with brownish lesions beginning to appear on stems with slight stunting; $2=$ all leaves wilted except top two or three, with 50\% stunting; $3=$ all leaves wilted and turned light tan, with 51 to $80 \%$ stunting; and 4 $=$ leaves defoliated and whole stem turned dark brown and withered, with severe stunting (dead plant). Reduced DSI compared to untreated control plants was used as an indicator of biological or chemical control efficacy.

In the second experiment, four Pseudomonas strains (6L10, 6ba6, 3ss9 and mbj) that caused a significant reduction in Phytophthora blight severity in the first experiment were applied for alone and in combination with olive oil by following the same procedure as in the first experiment. The treatments consisted of four bacterial inoculations with and without olive oil, ASM and ASM + mefenoxam, olive oil and uninoculated control. In the case of olive oil, $5 \mathrm{~mL}$ was applied by soil drench at the base of the stem of each pepper plant and then bacterial inoculum was applied as described above. The second experiment was evaluated in the same manner as in the first.

Experimental design and data analysis. In vitro tests including inhibition of mycelial growth of $P$. capsici, production of biosurfactants, indolic compounds, HCN, siderophore, extracellular enzyme activities and phosphate solubilization of bacteria were performed in a completely randomized design with 3 replicates. The pot experiments were established in a randomized complete block design with three replicates. Each treatment has ten pots in each replicate block. All the tests and in vivo experiments were repeated at least once. Data were subjected to analysis of variance with the general linear models procedure of JMP statistical software (Mac version 9.0.2, SAS Institute Inc., Cary, NC, USA). Mean separations were determined by Tukey's HSD (honestly significant difference) test at $P=$ 0.05 .

\section{Results}

Primary screen and in vitro biocontrol activities. From the one hundred one isolates obtained from the roots of different plants, only twenty four Pseudomonas isolates showed significant inhibition of vegetative growth of $P$. capsici in vitro. Fifteen of these isolates had significantly higher activity, with more than $50 \%$ inhibition on PDA plates while the remaining isolates had between 3.6\% and 49.3\% inhibition. Of the 24 Pseudomonas isolates, eleven produced biosurfactants on CTAB-methylene blue indicator plates containing glycerol as the carbon source (Table 1). Among the 11 isolates with biosurfactant-producing ability, strains 6ba6, 6ba2, 3ss9, 6L10 and 3k9 showed high production of biosurfactants, while the other six strains (6ba3, 6t14, ke, 6L14, mbj and 3tg8) demonstrated low biosurfactant production. Fatty acid methyl esters (FAME) analysis identified strains as Pseudomonas fluorescens (6ba6, 3ss9, 6L10, ke, 3k9, 6L14 and mbj) and Pseudomonas sp. (6ba2, 6ba3, 6t14 and 3tg8) with a similarity index of 0.80 or higher (Table 1$)$.

Mechanism of action of selected Pseudomonas strains. Of the 11 Pseudomonas isolates assessed for inorganic phosphate solubilization, only 10 solubilized $\mathrm{Ca}_{3}\left(\mathrm{PO}_{4}\right)_{2}$ in the qualitative P-solubilization plate method, and 11 isolates produced indolic compounds from L-tryptophan in vitro. Among the 11 strains of Pseudomonas tested for $\mathrm{HCN}$ production, only strains $6 \mathrm{ba} 2,3 \mathrm{ss} 9,6 \mathrm{~L} 10$, ke, $3 \mathrm{k} 9$, 6L14 and mbj showed high production of HCN. The other four strains $(6 \mathrm{ba} 6,6 \mathrm{ba} 3,6 \mathrm{t} 14,3 \mathrm{tg} 8)$ produced less HCN. 
Table 2. Effects of fungicide sprays applied to the foliage and bacterial isolates applied as a soil drench separately or in combination with olive oil on Phytophthora blight of pepper

\begin{tabular}{|c|c|c|c|c|}
\hline \multirow{2}{*}{ Treatments } & \multicolumn{2}{|c|}{$1^{\text {st }}$ Experiment } & \multicolumn{2}{|c|}{$2^{2^{\text {nd }}}$ Experiment } \\
\hline & Mean DSI ${ }^{a}$ & Percent control $^{\mathrm{b}}$ & Mean DSI ${ }^{a}$ & Percent control $^{\mathrm{b}}$ \\
\hline Acibenzolar-S-methyl + mefenoxam & $0.0 \mathrm{a}$ & 100.0 & $0.0 \mathrm{a}$ & 100.0 \\
\hline Acibenzolar-S-methyl & $2.1 \mathrm{c}$ & 32.3 & $2.6 \mathrm{~d}$ & 29.7 \\
\hline 6L10 & $1.2 \mathrm{~b}$ & 61.3 & $1.6 \mathrm{c}$ & 56.8 \\
\hline $6 \mathrm{ba} 6$ & $1.2 \mathrm{~b}$ & 61.3 & $1.5 \mathrm{c}$ & 59.5 \\
\hline $3 \mathrm{ss} 9$ & $1.6 \mathrm{~b}$ & 48.4 & $2.0 \mathrm{~cd}$ & 45.9 \\
\hline $\mathrm{mbj}$ & $1.9 \mathrm{c}$ & 38.7 & $2.6 \mathrm{~d}$ & 29.7 \\
\hline 6ba6+Olive oil & & & $0.7 \mathrm{~b}$ & 81.1 \\
\hline 6L10+Olive oil & & & $0.8 \mathrm{~b}$ & 78.4 \\
\hline 3ss9+Olive oil & & & $0.9 \mathrm{~b}$ & 75.7 \\
\hline mbj+Olive oil & & & $1.6 \mathrm{c}$ & 56.8 \\
\hline $6 \mathrm{ba} 2$ & $2.2 \mathrm{c}$ & 29.0 & & \\
\hline $3 \mathrm{k} 9$ & $2.2 \mathrm{c}$ & 29.0 & & \\
\hline Olive oil & & & $2.3 \mathrm{~d}$ & 37.8 \\
\hline Untreated control & $3.1 \mathrm{~d}$ & & $3.7 \mathrm{e}$ & \\
\hline
\end{tabular}

${ }^{a}$ In each column, the mean DSI (disease severity index) values that are followed by the same letter are not significantly different according to Tukey's HSD test at the $P=0.05$ level

${ }^{\mathrm{b}}$ Data represent percent control of Phytophthora blight by treatments (relative to untreated control).

All isolates produced siderophores on CAS medium, and the capacity for siderophore production was found to be highly dependent on the antagonistic potential of each Pseudomonas isolate as in Table 1. Maximum siderophore production was recorded in Pseudomonas isolates 6ba6, $6 \mathrm{ba} 2,6 \mathrm{ba} 3$ and $6 \mathrm{t} 14$. Eleven isolates produced a 629-bp DNA product in a PCR-based assay using a primer set that amplifies the phlD gene, which encodes the antifungal agents. Of the eleven isolates, four of which had strong protease activity (6ba6, 6ba2, 6L10 and 6L14), and 5 of which had weak protease activity (6ba3, 3ss 9 , ke, $3 \mathrm{k} 9$ and $\mathrm{mbj}$ ) while the remaining two (6t14 and $3 \operatorname{tg} 8)$ exhibited no protease activity in an in vitro plate assay. None of the biosurfactant producing Pseudomonas isolates showed cellulase or chitinase activity in vitro.

The five high biosurfactant-producing strains (6ba6, 6ba2, $3 \mathrm{ss} 9,6 \mathrm{~L} 10$ and $3 \mathrm{k} 9$ ) and $\mathrm{mbj}$ were selected for evaluation of biocontrol activity in the greenhouse.

Greenhouse experiment. Pepper plants in the first and second experiments began showing symptoms of infection, including wilt, stunting and lesions at the bases of the stems, seven days after inoculation with P. capsici. In both experiments, all treatment groups (ASM, ASM + mefenoxam, and all tested bacterial isolates with and without olive oil) significantly reduced disease severity compared to the untreated control (Table 2). When analyzing the results obtained in both experiments, it was found that the most effective treatment for inhibiting the development of lesions on pepper plants inoculated with $P$. capsici was foliar spraying of ASM + mefenoxam at $0.2 \mathrm{mg}$ product/ $\mathrm{ml}$.

In the first experiment, the six biosurfactant producing bacterial isolates applied by soil drenching significantly $(P$ $<0.05$ ) reduced disease severity of Phytophthora blight on pepper compared to the untreated control (Table 2). Among these six isolates, isolates $6 \mathrm{~L} 10,6 \mathrm{ba} 6$ and $3 \mathrm{ss} 9$ provided significant control of the disease, by $61.3,61.3$ and $48.4 \%$, respectively. The other three isolates (mbj, 6ba2 and $3 \mathrm{k} 9)$, including foliar application of ASM, were less effective, with the control ranging from 29 to $38.7 \%$. Foliar applications of ASM at $0.2 \mathrm{mg}$ a.i./ $/ \mathrm{mL}$ were phytotoxic, causing the edges of leaves to curl up. Pseudomonas isolates 6L10, 6ba6, 3ss9 and mbj were selected as potentially effective antagonists for the second greenhouse experiment.

In the second experiment, Pseudomonas isolates 6L10, 6ba6, 3ss9 and mbj were evaluated separately or in combination with olive oil for efficacy against $P$. capsici under greenhouse conditions. When compared with the untreated control, the treatments of the four bacterial isolates applied as a soil drench or in combination with olive oil significantly reduced the severity of the disease. However, the treatments with individual bacterial isolates combined with olive oil consistently resulted in significantly $(P>0.05)$ lower disease severity than the same isolates applied alone. Among the treatments that included olive oil, isolates 6ba6, 6L10 and 3ss9, and to a lesser extent mbj, significantly reduced disease severity by $81.1,78.4,75.7$, and $56.8 \%$, 
respectively (Table 2). The same bacterial isolates applied without olive oil, as well as the treatment with olive oil alone, also had a significant but smaller effect on disease reduction compared to the untreated control. Similarly, foliar application of ASM (0.2 mg a.i./mL) was less effective, with control efficiencies of $29.7 \%$, but the same phytotoxicity symptoms recurred in the second experiment.

\section{Discussion}

Efficient control of plant pathogens in agricultural systems by any chemical or biological agent depends mainly on the mode-of-action by which the agent causes permanent or temporary damage to the life cycle of the pathogen. Considering the disease cycle of $P$. capsici, dormant oospores germinate during wet conditions to produce lemon-shaped sporangia, which may germinate directly or release swimming zoospores, and the infection and subsequent sporulation on host tissue provide the greatest opportunity for host infection and disease development in the field (Hausbeck and Lamour, 2004).

Our experiments on suppression of Phytophthora blight disease of pepper showed that foliar application of acibenzolar-S-methyl + mefenoxam $(0.2 \mathrm{~g}$ product $/ \mathrm{ml})$ gave the highest disease suppression, $100 \%$. Mefenoxam, an active isomer of metalaxyl, has historically been used to control $P$. capsici on pepper plants (Foster and Hausbeck, 2010; Matheron and Porchas, 2000). A very high efficiency of $\mathrm{ASM}+$ mefenoxam applications in our greenhouse studies could also be attributed to the presence of acibenzolar- $S$ methyl in the product that we used (Görlach et al., 1996; Matheron and Porchas, 2002).

Biosurfactants are surface-active substances produced by variety of microorganisms. Production of biosurfactants is a common feature in bacteria, including many plant beneficial and plant pathogenic Pseudomonas spp., which produce primarily cyclic lipopeptide- and rhamnolipid-type biosurfactants (D'aes et al., 2010). Kim et al. (2000) confirmed that rhamnolipid B, isolated from Pseudomonas aeruginosa strain B5, inhibits zoospore germination and hyphal growth of $P$ capsici. The efficacy of rhamnolipid B against Phytophthora blight was similar to that of metalaxyl on pepper plants when treated just before inoculation with $P$. capsici under greenhouse conditions. The results from our study indicated that biosurfactant-producing Pseudomonas isolates applied as a soil drench significantly reduced disease severity of Phytophthora blight on pepper plants under greenhouse conditions and that olive oil combinations of Pseudomonas isolates applied as a soil drench much more increased the efficacy of disease control against $P$. capsici. Three out of six biosurfactant-producing Pseudomonas isolates, 6ba6, 6L10 and 3ss9, consistently provided effective control of Phytophthora blight in both greenhouse tests. These three biosurfactant producers, identified as Pseudomonas fluorescens, are equipped with additional biocontrol mechanisms, such as production of $\mathrm{HCN}$, indolic compounds, siderophore, extracellular protease and presence of antibiotic production gene (Table 1).

P. fluorescens has been reported to produce a diverse array of antibiotics (phenazines, pyrrolnitrin, pyoluteorin and 2,4-diacetylphloroglucinol), which are largely responsible for the biocontrol effectiveness of this bacterium (Cui and Harling, 2006). All effective strains in our study have the phlD gene for the production of antibiotics. The antibiotic 2,4-DAPG, a broad-spectrum antibiotic produced by Pseudomonas biocontrol strains, has a widespread effect on a variety of root and seedling diseases (De Souza et al., 2003). Hydrogen cyanide (HCN), a volatile antibiotic produced by many antagonistic $P$. fluorescens strains, particularly those that produce 2,4-DAPG, has been recognized as a significant factor in the control of many soil-borne fungal pathogens (Haas and Keel, 2003). As shown in Table 1, our most effective Pseudomonas fluorescens strains are found to secrete fluorescent, yellow-green, water soluble siderophores. Since their first demonstration by Kloepper et al. (1980) as a mechanism of biological control, siderophores have been clearly evidenced in the control of Pythium and Fusarium species, and have also been known to induce systemic resistance in plants (Van Loon et al., 1998).

Although individual biocontrol strains are equipped with multiple biocontrol mechanisms, further efforts are often required to enhance practical acceptance of biological disease control and to replace environmentally hazardous alternatives. One recent approach for enhancement of biocontrol efficacy is to combine the bacterial isolates selected for controlling P. capsici (Kim et al., 2008a; Zhang et al., 2010). Yet another strategy to boost biocontrol efficiency and consistency is the use of specific nutrient sources as amendments to biocontrol agents. Control of Phytophthora blight of pepper was enhanced by the addition of organic materials to the soil (Nam et al., 1988), the use of the biocontrol agents with other materials (Lee et al., 1999), the addition of chitin to the soil (Chae et al., 2006) and the addition of L-arabinose and $\mathrm{D}(+)$-glucose to antagonistic bacterial (Chryseobacterium strain KJ1R5) suspensions (Kim et al., 2008b). Likewise, Jiang et al. (2006) showed that use of a mixture of two Bacillus strains with rape seed residue and compost before application provided better control of Phytophthora blight of bell pepper and also greater yield increases than all other methods under field conditions.

In the present study, we clearly demonstrated that amendment of the soil with olive oil significantly increased the efficacy of biocontrol activity of biosurfactant-producing 
antagonistic Pseudomonas strains against $P$. capsici, suggesting that olive oil could be applied to enhance their biocontrol efficacy. Although olive oil is one of the best carbon sources for surfactant synthesis (Abouseoud et al., 2008; Stanghellini and Miller, 1997), the price and availability of olive oil could be a limiting factor for its widespread practical application. However, Turkey is one of the five most important olive- and olive oil-producing countries in the world, and tons of olive oil processing waste are discharged during olive oil extraction. Thus, olive oil mill effluent could be a good potential substrate for biosurfactantproducing bacteria (Mercade et al., 1993; Mercade and Manresa, 1994), as previously demonstrated for weed control in Turkey (Boz et al., 2003). The efficacy of our Pseudomonas strains (when introduced either alone or in combination with olive oil or olive oil processing waste) for the suppression of Phytophthora blight of pepper and for yield enhancement under field conditions are worthy of further investigation.

\section{References}

Abouseoud, M., Maachi, R., Amrane, A., Boudergua, A. and Nabi, A. 2008. Evaluation of different carbon and nitrogen sources in production of biosurfactant by Pseudomonas fluorescens. Desalination 223:143-151.

Akgül, S. D. and Mirik, M. 2008. Biocontrol of Phytophthora capsici on pepper plants by Bacillus megaterium strains. $J$. Plant Pathol. 90:29-34.

Alegbejo, M. D., Lawal, A. B. and Chindo, P. S. 2006. Outbreak of basal stem rot and wilt disease of pepper in Katsina, Nigeria. Arch. Phytopathol. PFL 39:93-98.

Aravind, R., Kumar, A., Eapen, S. J. and Ramana, K. V. 2009. Endophytic bacterial ora in root and stem tissues of black pepper (Piper nigrum L.) genotype: isolation, identication and evaluation against Phytophthora capsici. Lett. Appl. Microbiol. 48:58-64.

Bakker, A. W. and Schippers, B. 1987. Microbial cyanide production in the rhizosphere in relation to potato yield reduction and Pseudomonas spp-mediated plant growth-stimulation. Soil Biol. Biochem. 19:451-457.

Baris, M., Gülsoy, E., Güncü, M., Maden, S., Sagir, A., Senyürek, M., Ulukus, İ., Yalcin, O. and Zengin, H. 1986. Investigations on the primary inoculum source and control measurements of the crown blight disease (Phytophthora capsici Leon.) of peppers. Plant Prot. Bull. 26:59-95 (in Turkish).

Berg, G., Frankowski, J. and Bahl, H. 2000. Interactions between Serratia plymuthica and the soil borne pathogen Verticillium longisporum. In Advances in Verticillium Research and Disease Management, eds. by E. C. Tjamos, C. Rowe, J. B. Heale, D. R. Fravel, pp. 269-273. St Paul, MN, USA: American Phytopathological Society Press.

Boz, Ö, Dogan, M. N. and Albay, F. 2003. Olive processing waste as a method of weed control. Weed Res. 43:439-443.
Castric, P. A. 1975. Hydrogen cyanide, a secondary metabolite of Pseudomonas aeruginosa. Can. J. Microbiol. 21:613-618.

Chae, D. H., Jin, R. D., Hwangbo, H., Kim, Y. W., Kim, Y. C., Park, R. D., Krishnan, H. B. and Kim, K. Y. 2006. Control of late blight (Phytophthora capsici) in pepper plant with a compost containing multitude of chitinase-producing bacteria. Biocontrol 51:339-351.

Chung, S., Kong, H., Buyer, J. S., Lakshman, D. K., Lydon, J., Kim, S. D. and Roberts, D. 2008. Isolation and partial characterization of Bacillus subtilis ME488 for suppression of soilborne pathogen of cucumber and pepper. Appl. Microbiol Biot. 80:115-123.

Cui, X. and Harling, R. 2006. Evaluation of bacterial antagonists for biological control of broccoli head rot caused by Pseudomonas fluorescens. Phytopathology 96:408-416.

D'aes, J., De Maeyer, K., Pauwelyn, E. and Höfte, M. 2010. Biosurfactants in plant-Pseudomonas interactions and their importance to biocontrol. Environ. Microbiol. Rep. 2:359-372.

Dai, X. Y. and Guan, G. L. 1999. Study on two strains of antagonistic bacteria producing antagonistic proteins to Phytophthora capsici. Chinese J. Biol. Control 15:81-84.

De Freitas, J. R., Banerjee, M. R. and Germida, J. J. 1997. Phosphate-solubilizing rhizobacteria enhance the growth and yield but not phosphorus uptake of canola (Brassica napus L.). Biol. Fert. Soils 24:358-364.

De Souza, J. T., Arnould, C., Deulvot, C., Lemanceau, P., Gianinazzi-Pearson, V. and Raaijmakers, J. M. 2003. Effect of 2,4diacetylphloroglucinol on Pythium: Cellular responses and variation in sensitivity among propagules and species. Phytopathology 93:966-975.

Dworkin, M. and Foster, J. W. 1958. Experiments with some microorganisms which utilize ethane and hydrogen. J. Bacteriol. 75:592-603.

Ezziyyani, M., Pérez, S. C., Requena, M. E., Sid, A. A. and Candela, M. E. 2004. Evaluación del biocontrol de Phytophthora capsici en pimiento (Capsicum annuum L.) por tratamiento con Burkholderia cepacia. An. Biol. 26:61-68.

Ezziyyani, M., Requena, M. E., Egea-Gilabert, C. and Candela, M. E. 2007. Biological control of Phytophthora root rot of pepper using Trichoderma harzianum and Streptomyces rochei in combination. J. Phytopathol. 155:342-349.

FAO, 2010. Statistical Databases (FAOSTAT). Food and Agriculture Organization of the United Nations. http://faostat3.fao.org /home/index.html (Accessed March 1, 2012).

Foster, J. M. and Hausbeck, M. K. 2010. Managing phytophthora crown and root rot in bell pepper using fungicides and host resistance. Plant Dis. 94:697-702.

Gordon, S. A. and Weber, R. P. 1951. Colorimetric estimation of indoleacetic acid. Plant Physiol. 26:192-195.

Görlach, J., Volrath, S., Knauf-Beiter, G., Hengy, G., Beckhove, U., Kogel, K. H., Oostendorp, S., Staub, T., Ward, E., Kessmann, H. and Ryals, J. 1996. Benzothiadiazole, a novel class of inducers of systemic acquired resistance, activates gene expression and disease resistance in wheat. Plant Cell 8:629643.

Guillén-Cruz, R., Hernández-Castillo, F. D., Gallegos-Morales, 
G., Rodríguez-Herrera, R., Aguilar-González, C. N., PadrónCorral, E. and Reyes-Valdés, M. H. 2006. Bacillus spp. como biocontrol en un suelo infestado con Fusarium spp., Rhizoctonia solani Kühn y Phytophthora capsici Leonina y su efecto en el desarrollo y rendimiento del cultivo de chile (Capsicum annuum L.). Rev. Mex. Fitopatol. 24:105-114.

Haas, D. and Keel, C. 2003. Regulation of antibiotic production in root-colonizing Pseudomonas spp. and relevance for biological control of plant disease. Annu. Rev. Phytopathol. 4:117153.

Hausbeck, M. K. and Lamour, K. H. 2004. Phytophthora capsici on vegetable crops: research progress and management challenges. Plant Dis. 88:1292-1303.

Jiang, Z., Guo, Y., Li, S., Qi, H. and Guo, J. 2006. Evaluation of biocontrol efciency of different Bacillus preparations and eld application methods against Phytophthora blight of bell pepper. Biol. Control 36:216-223.

Jung, H. K. and Kim, S. D. 2003. Purication and characteriztion of an antifungal antibiotic from Bacillus megaterium KL 39, a biocontrol agent of red-papper Phytophtora blight disease. Kor. J. Microbiol. Biotechnol. 31:235-241.

Jung, H. K. and Kim, S. D. 2004. Selection and antagonistic mechanism of Pseudomonas uorescens 4059 against phytophthora blight disease. Kor. J. Microbiol. Biotechnol. 32:312316.

Jung, H. K. and Kim, S. D. 2005. An antifungal antibiotic puried from Bacillus megaterium KL39, a biocontrol agent of redpepper Phytophthora-blight disease. J. Microbiol. Biotechnol. 15:1001-1010.

Kasana, R., C., Salwan, R., Dhar, H., Dutt, S. and Gulati, A. 2008. A rapid and easy method for the detection of microbial cellulases on agar plates using Gram's iodine, Curr. Microbiol. 57:503-507.

Kim, B. S., Lee, J. Y. and Hwang, B. K. 2000. In vivo control and in vitro antifungal activity of rhamnolipid $\mathrm{B}$, a glycolipid antibiotic, against Phytophthora capsici and Colletotrichum orbiculare. Pest Manag. Sci. 56:1029-1035.

Kim, S. G., Jang, Y., Kim, H. Y., Koh, Y. J. and Kim, Y. H. 2010. Comparison of microbial fungicides in antagonistic activities related to the biological control of phytophthora blight in chili pepper caused by Phytophthora capsici. Plant Pathol. J. 26:340-345.

Kim, Y. C., Jung, H., Kim, K. Y. and Park, S. K. 2008a. An effective biocontrol bioformulation against Phytophthora blight of pepper using growth mixtures of combined chitinolytic bacteria under different field conditions. Eur. J. Plant Pathol. 120:373-382.

Kim, Y. S., Jang, B., Chung, I. M., Sang, M. K., Ku, H. M., Kim, K. D. and Chun, S. C. 2008b. Enhancement of biocontrol activity of antagonistic Chryseobacterium strain KJ1R5 by adding carbon sources against Phytophthora capsici. Plant Pathol. J. 24:164-170.

King, E. O., Ward, M. K. and Raney, D. E. 1954. Two simple media for the demonstration of pyocyanin and uorescin. $J$. Lab. Clin. Med. 44:301-307.

Kloepper, J. W., Leong, J., Teintze, M. and Schroth, M. N. 1980.
Pseudomonas siderophores: A mechanism explaining disease suppression in soils. Curr. Microbiol. 4:317-320.

Krechel, A., Faupel, A., Hallmann, J., Ulrich, A. and Berg, G. 2002. Potato associated bacteria and their antagonistic potantial towards plant-pathogenic fungi and the plant-parasitic nematode Meloidogyne incognita (Kofoid \& White) Chitwood. Can. J. Microbiol. 48:772-786.

Kurze, S., Bahl, H., Dahl, R. and Berg, G. 2001. Biological control of fungal strawberry disease by Serratia plymuthica HRAC48. Plant Dis. 85:529-534.

Lamour, K. H. and Hausbeck, M. K. 2001. The dynamics of mefenoxam insensitivity in a recombining population of $P h y$ tophthora capsici characterized with amplified fragment length polymorphism markers. Phytopathology 91:553-557.

Lee, E. T., Lim, S. K., Nam, D. H., Khang, Y. H. and Kim, S. D. 2003a. Pyoverdin 2112 of Pseudomonas uorescens 2112 inhibits Phytophthora capsici, a red-pepper blight-causing fungus. J. Microbiol. Biotechnol. 13:415-421.

Lee, J. Y. and Hwang, B. K. 2002. Diversity of antifungal actinomycetes in various vegetative soils of Korea. Can. J. Microbiol. 48:407-417.

Lee, J. Y., Kim, B. S., Lim, S. W., Lee, B. K., Kim, C. H. and Hwang, B. K. 1999. Field control of phytophthora blight of pepper plants with antagonistic rhizobacteria and DL- $\beta$-aminon-butyric acid. Plant Pathol. J. 15:217-222.

Lee, J. Y., Moon, S. S. and Hwang, B. K. 2003b. Isolation and antifungal and antiomycete activities of aerugine produced by Pseudomonas uorescens strain MM-B16. Appl. Environ. Microb. 69:2023-2031.

Lee, J. Y., Moon, S. S. and Hwang, B. K. 2003c. Isolation and in vitro and in vivo activity against Phytophthora capsici and Volletoteichum orbiculare of phenazine-1-carboxylic acid from Pseudomonas aeruginosa strain GC-B26. Pest Manag. Sci. 59:872-882.

Leeman, M., Denouden, E. M., van Pelt, J. A., Dirkx, F., Steijl, H., Bakker, P. and Schippers, B. 1996. Iron availability affects induction of systemic resistance to fusarium wilt of radish by Pseudomonas fluorescens. Phytopathology 86:149-155.

Ma, Y., Chang, Z., Zhao, J. and Zhou, M. 2008. Antifungal activity of Penicillium striatisporum Pst10 and its biocontrol effect on Phytophthora root rot of chilli pepper. Biol. Control 44:2431.

Matheron, M. E. and Porchas, M. 2000. Comparison of five fungicides on development of root, crown, and fruit rot of chile pepper and recovery of Phytophthora capsici from soil. Plant Dis. 84:1038-1043.

Matheron, M. E. and Porchas, M. 2002. Suppression of Phytophthora root and crown rot on pepper plants treated with acibenzolar-S-methyl. Plant Dis. 86:292-297.

McSpadden Gardener, B. B., Mavrodi, D. V., Thomashow, L. S. and Weller, D. M. 2001. A rapid polymerase chain reactionbased assay characterizing rhizosphere populations of 2,4-diacetylphloroglucinolproducing bacteria. Phytopathology 91: 44-54.

Mercade, M. E. and Manresa, M. A. 1994. The use of agroindustrial by-products for biosurfactant production. J. Am. Oil 
Chem. Soc. 71:61-64.

Mercade, M. E., Manresa, M. A., Robert, M., Espuny, M. J., Andres, C. and Guinea, J. 1993. Olive oil mill effluent (OOME): new substrate for biosurfactant production. Bioresource Technol. 43:1-6.

Nam, C. G., Jee, H. J. and Kim, C. H. 1988. Studies on biological control of Phytophthora blight of Red-pepper II. Enhancement of antagonistic activity by soil amendment with organic materials. Kor. J. Plant Pathol. 4:313-318.

Nielsen, C. J., Ferrin, D. M. and Stanghellini, M. E. 2006. Efficacy of biosurfactants in the management of Phytophthora capsici on pepper in recirculating hydroponic systems. Can. J. Plant Pathol. 28:450-460.

Okomoto, H., Sato, M., Sato, Z. and Isaka, M. 1998. Biological control of Phytopthora capsici by Serratia marcescence F-1-1 and analysis of biocontrol mechanisms using transposon insertion mutants. Ann. Phytopathol. Soc. Japan 64:287-293.

Ölmez, F. 2006. Determination of The Effect of Organic Matter and Pumice Usage to Pepper Root and Crown Rot (Phytophthora capsici Leon). MsC Thesis, University of Çukurova, Adana, Turkey (in Turkish).

Park, H. J., Lee, J. Y., Hwang, I. S., Yun, B. S., Kim, B. S. and Hwang, B. K. 2006. Isolation and antifungal and antioomycete activities of staurosporine from Streptomyces roseoavus strain LS-A24. J. Agr. Food Chem. 54:3041-3046.

Patten, C. L. and Glick, B. R. 2002. Role of Pseudomonas putida Indoleacetic acid in development of the host plant root system. Appl. Environ. Microbiol. 68:3795-3801.

Qiu, S. X., He, H., Ruan, H. C., Guan, X. and Hu, F. P. 2004. Biological control of pepper Phytophthora blight by endophytic TB2 (Bacillus sp.). Acta Phytopathol. Sin. 34:173-179.

Robles-Yerena, L., Rodríguez-Villarreal, R. A., Ortega-Amaro, M. A., Fraire-Velázquez, S., Simpson, J., Rodríguez-Guerra, R. and Jiménez-Bremont, J. F. 2010. Characterization of a new fungal antagonist of Phytophthora capsici. Sci. Hortic-Amster- dam 125:248-255.

Sang, M. K., Chun, S. C. and Kim, K. D. 2008. Biological control of Phytophthora blight of pepper by antagonistic rhizobacteria selected from a sequential screening procedure. Biol. Control 46:424-433.

Schwyn, B. and Neilands, J. B. 1987. Universal chemical assay for the detection and determination of siderophores. Anal. Biochem. 160:47-56.

Shen, S. S., Choi, O. H., Park, S. H., Kim, C. G. and Park, C. S. 2005. Root colonizing and biocontrol competency of Serratia plymuthica A21-4 against Phytophthora blight of pepper. Plant Pathol. J. 21:64-67.

Sid, A., Ezziyyani, M., Egea-Gilabert, C. and Candela, M. E. 2003. Selecting bacterial strains for use in the biocontrol of diseases caused by Phytophthora capsici and Alternaria alternata in sweet pepper plants. Biol. Plant. 47:569-574.

Siegmund, I. and Wagner, F. 1991. New method for detecting rhamnolipid excreted by Pseudomonas species during growth on mineral agar. Biotechnol. Tech. 5:265-268.

Silvar, C., Merino, F. and Díaz, J. 2006. Diversity of Phytophthora capsici in northwest Spain: Analysis of virulence, metalaxyl response, and molecular characterization. Plant Dis. 90:1135-1142.

Stanghellini, M. E. and Miller, R. M. 1997. Biosurfactants, their identity and potential efficacy in the biological control of zoosporic plant pathogens. Plant Dis. 81:4-12.

Van Loon, L. C., Bakker, P. A. H. M. and Pieterse, C. M. 1998. Systemic resistance induced by rhizosphere bacteria. Аnnu. Rev. Phytopathol. 36:453-483.

Zhang, S., White, T. L., Martinez, M. C., McInroy, J. A., Kloepper, J. W. and Klassen, W. 2010. Evaluation of plant growthpromoting rhizobacteria for control of Phytophthora blight on squash under greenhouse conditions. Biol. Control 53:129135. 